\title{
Da tortura ao corpo torturado: A narrativa como resistência no conto $O$ Leite em Pó
}

\section{da Bondade Humana}

\author{
From torture to the tortured body: Narrative as resistance in the story $O$ Leite em Pó da Bondade
}

\section{Humana}

De la tortura al cuerpo torturado: La narrativa como resistencia en la historia $O$ Leite em Pó da Bondade Humana

Recebido: 14/01/2022 | Revisado: 18/01/2022 | Aceito: 22/01/2022 | Publicado: 24/01/2022

\author{
Maria Genailze de Oliveira Ribeiro Chaves \\ ORCID: https://orcid.org/0000-0003-3088-9309 \\ Universidade Federal do Pará, Brasil \\ E-mail: maria.genailze@gmail.com \\ Francisco Pereira Smith Júnior \\ ORCID: https://orcid.org/0000-0002-6336-9249 \\ Universidade Federal do Pará, Brasil \\ E-mail: fransmithj@gmail.com
}

\begin{abstract}
Resumo
Com uma hermenêutica histórica e social, por meio da interdisciplinaridade entre história, sociologia e literatura, analisa-se no presente artigo a relação temática da tortura e do corpo torturado, a partir da literatura de testemunho, especificamente do teor testemunhal, no conto O Leite em Pó da Bondade Humana, (1983) de Haroldo Maranhão. Nesse viés, o objetivo do trabalho está em explorar a violência diante do corpo torturado na obra supracitada. Assim, a manifestação literária nessa narrativa, no contexto contemporâneo da literatura brasileira, amazônida e paraense, permite perceber que a obra estudada é parte dos acervos narrativos da literatura de testemunho, especificamente de teor testemunhal, que se firmam a partir do século XX, concomitante a isso se conhece a opressão política, bem como expõe as atrocidades que sofriam os presos políticos durante a ditadura militar de 1964 no Brasil, em que descortina um cenário real vivenciado por pessoas que resistiram as repressões dessa época.
\end{abstract}

Palavras-chave: Tortura; Corpo torturado; Ditadura militar; Ficção; Teor testemunhal.

\begin{abstract}
With a historical and social hermeneutics, through the interdisciplinarity provided in this work by the link between history, sociology and literature, this article analyzes the thematic relationship between torture and the tortured body, based on the testimonial literature, specifically the testimonial content. in the short story O Leite em Pó da Bondade Humana (1983) by Haroldo Maranhão. In this bias, the objective of the work is to explore the violence in front of the tortured body in the aforementioned work. Thus, the literary manifestation in this narrative, in the contemporary context of Brazilian, Amazonian and Pará literature, allows us to perceive that the work studied is part of the narrative collections of testimonial literature, specifically of testimonial content, which are established from the XX th century, concomitant political oppression is known, as well as exposing the atrocities that political prisoners suffered during the 1964 military dictatorship in Brazil, in which it reveals a real scenario experienced by people who resisted the repressions of that time.
\end{abstract}

Keywords: Torture; Tortured body; Military dictatorship; Fiction; Testimonial content.

\section{Resumen}

Con una hermenéutica histórica y social, a través de la interdisciplinariedad que en este trabajo brinda el vínculo entre historia, sociología y literatura, este artículo analiza la relación temática entre la tortura y el cuerpo torturado, a partir de la literatura testimonial, específicamente del contenido testimonial. el cuento O Leite em Pó da Bondade Humana (1983) de Haroldo Maranhão. En este sesgo, el objetivo del trabajo es explorar la violencia frente al cuerpo torturado en la citada obra. Así, la manifestación literaria en esta narrativa, en el contexto contemporáneo de la literatura brasileña, amazónica y pará, permite percibir que la obra estudiada forma parte de los acervos narrativos de literatura testimonial, específicamente de contenido testimonial, que se establecen a partir del siglo XX. siglo, concomitantemente se conoce la opresión política, además de exponer las atrocidades que sufrieron los presos políticos durante la dictadura militar de 1964 en Brasil, en lo que revela un escenario real vivido por personas que resistieron las represiones de esa época.

Palabras clave: Tortura; Cuerpo torturado; Dictadura militar; Ficción; Contenido testimonial. 


\section{Introdução}

Baseado no conto $O$ Leite em Pó da Bondade Humana (1983), de Haroldo Maranhão, obra ficcional que aborda a ditadura militar no Brasil, o presente artigo consiste numa análise temática da tortura e do corpo torturado representadas na narrativa supracitada, compreendendo as violências sofridas pelos personagens ao longo do texto.

Por esse viés, adentrando o momento histórico brasileiro mais obscuro, os Anos de Chumbo, Arns (1987) evidencia que a ditadura militar mudou o Brasil entre 1964 e 1979: Economia, política, cultura e sociedade. Depois de instaurada, radicalizou-se como um programa político nacionalista e popular. Usou-se de maneira velada, mas sistemática da tortura contra as atividades consideradas "subversivas".

A obra As peles frias é uma coletânea de contos que reflete situações surreais, absurdas, mas que são tidas com toda naturalidade. Já o conto $O$ Leite em pó da Bondade Humana, é o único dessa coleção que quebra com esses pressupostos, diferentemente, ele é deslocado de Chapéus de três Bicos, onde encontra-se um clima bastante diverso, com realidades sórdidas, sem meias palavras, que evidenciam a vida política e opressora brasileira mais recente. Assim, por meio de uma narrativa ficcional e histórica de teor testemunhal, o conto, com o uso de um narrador personagem, elucida as atrocidades cometidas durante sessões de tortura dos mais variados tipos, que ocorriam durante a ditadura militar no Brasil, mostrando através de um texto exclusivamente em $1^{\mathrm{a}}$ pessoa, e com uma linguagem abjeta ${ }^{1}$ as violências em cárcere em um período de autoritarismo.

Assim, o objetivo do artigo está em explorar a tortura e o corpo torturado, destacando a atuação da literatura testemunho no conto. Portanto, tem-se como hipótese que esse texto, por intermédio das temáticas trabalhadas em sua narrativa de teor testemunhal, denuncia as questões temporais/reais e sociopolíticas veladas durante a ditadura militar no Brasil.

\section{Metodologia}

O presente artigo desenvolveu-se a partir da hermenêutica histórica que por meio do seu caráter qualitativo abrange discussões sociais propiciadas nesse trabalho pelo elo interdisciplinar entre a literatura e outras ciências. Por esse viés, O método histórico baseia-se na premissa da História como ciência e disciplina, sendo ela capaz de explicar as estruturas e acontecimentos nas esferas sociais, politicas e econômicas. Esse fenômeno analítico contextualiza como se organiza a sociedade em diferentes épocas. (Goldman, 1994).

Acerca do processo interdisciplinar baseou-se nos estudos de Carvalhal (2006), em que teoriza a interdisciplinaridade como parte dos estudos literários. Trata-se da relação entre literatura e outras áreas do conhecimento como a filosofia, história, ciências sociais, podendo elas ser políticas, econômicas, sociológicas, além dos mais diversos campos que seja permitido essas relações. Sendo assim, é o diálogo entre literaturas, e literatura com outros campos de representação humana.

\section{Literatura de Testemunho e Teor Testemunhal}

Desde o século $\mathrm{XX}$, cada vez mais, está sendo estudada às inúmeras catástrofes e violências sucedidas nesse período. Segundo Seligmann-Silva (2003) o momento histórico demarcado traz consigo um grandioso número de acontecimentos catastróficos que culminaram em um número expressivo de pessoas torturadas e mortas. Com isso, instauramse nos escritos literários um novo modo de se escrever esses fatos, um molde que não se foca no estilo, mas sim na temática e no conteúdo, descrevendo o mais símil os fatos dessa época.

${ }^{1}$ A linguagem abjeta, segundo Ramos (2019), faz referência, portanto, ao que ainda não se materializou em corpo-significado no domínio social, sendo esse corpo social "expurgado, rejeitado, negado; aquilo que, na compreensão do dicionário é referenciado como ato, estado ou condição que revela alto grau de baixeza, torpeza, degradação" (p. 19). 
O termo Resistência e suas aproximações com os termos "cultura", "arte", "narrativa" foram pensados e formulados no período que ocorre, aproximadamente, entre 1930 e 1950, quando numerosos intelectuais se engajaram no combate ao fascismo, ao nazismo e as suas formas aparentadas, o franquismo e o salazarismo. [...]. Firmou-se ao longo desses anos sombrios uma frente de caráter libertador que, em luta de guerrilhas e emboscadas, o maquis (de macchia, no sentido corso de moita onde entocaiavam os resistentes), disputava palmo a palmo as áreas invadidas. (Bosi, 2000, p. 125)

Por esse caminho, esse período é marcado por uma nova elaboração artística, cultural e narrativa, em que a resistência porta uma carga significativa, de cunho libertador. Os intelectuais da época trazem em sua arte um meio de combater, com seus talentos, os variados grupos de opressão. Assim, no século XX, surge a literatura de testemunho, "um conceito que, nos últimos anos, tem feito com que muitos teóricos revejam a relação entre a literatura e a "realidade" (Seligmann-Silva, 2003, p. 47).

Compreende-se que, até esse período, a literatura desde seus primeiros escritos, por meio da mimese, buscou assemelhar o mais verossímil à realidade vivenciada pelo corpus social. Esse processo, em muitas análises realizadas durante anos, mostrou a literatura como imitação e representação da natureza. No entanto, a partir das catástrofes que marcaram o pósguerra, a literatura de testemunho vem moldar esses processos de expressão da realidade, que "ao invés da tradicional representação, o seu registro é do índice: ela quer apresentar, expor o passado, seus fragmentos, ruínas e cicatrizes" (Seligmann-Silva, 2003, p. 57).

Novamente Seligmann-Silva (2003) evidencia que a literatura de testemunho, “[...] desconstrói a historiografia tradicional (e também os tradicionais gêneros literários) ao incorporar elementos antes reservados à ficção. A leitura estética do passado é necessária, pois opõe-se à "musealização" do ocorrido: ela está vinculada a uma modalidade da memória que quer manter o passado ativo no presente." (p. 57, grifo meu)

É um processo de escrita que conta fatos passados com uma linguagem que possibilita não apenas um passeio ao passado, no entanto por meio de experiências traumáticas do eu ou do outro, propicia que se viva as dores e os acontecimentos diante de uma realidade violenta. Nesse sentido, temos como elemento desse conceito, aquele que testemunha, o narrador que relata os acontecimentos no texto, trata-se da testemunha testis, superstes e arbiter.

Verificamos a diferença entre superstes e testis. Etimologicamente, testis é aquele que assiste como um «terceiro» (terstis) a um caso em que dois personagens estão envolvidos; e essa concepção remonta ao período indo-europeu comum. Um texto sânscrito enuncia: «todas as vezes em que duas pessoas estão presentes, Mitra está lá como terceira pessoa»; assim o deus Mitra é, por natureza, a «testemunha». Mas superstes descreve a «testemunha» seja como aquele «que subsiste além de», testemunha ao mesmo tempo sobrevivente, seja como «aquele que se mantém no fato», que está aí presente. (Beveniste apud Seligmann-Silva, 2010, p. 4)

No Arbiter, conceito novo criado pelo professor Sarmento-Pantoja (2019) no artigo O testemunho em três vozes: Testis, Superstes e Arbiter, trata-se da "narração realizada por meio da recuperação do testemunho ouvido. [...] Daquele que ouviu e arbitra o que e como narrar, deve ser validado como parte de uma tríade testemunhal, já que se encontra imiscuído às outras formas de testemunho" (p. 5).

Portanto, a partir dos escritos de Seligmann-Silva (2003) infere-se que a literatura de testemunho, com sua testemunha, provoca a tensão do que há no "real", entre a afirmação e a negação, em que sua existência está marcada no espaço entre as palavras e as "coisas”, “o testemunho tem sempre parte com a possibilidade de ao menos da ficção, do perjúrio e da mentira, afirma Derrida. Eliminada essa possibilidade, nenhum testemunho será possível e, de todo modo, não terá mais o sentido do testemunho" (p. 374). Compreende-se, que a presença da ficção demarca a literatura de testemunho, onde ela não se fizer presente não há literatura de testemunho, o que se tem é uma concepção jurídica de testemunho. 
Nessa lógica, cabe compreender que na literatura de testemunho, a definição de testemunho é aberta, já que não só aquele que viveu um martírio pode testemunhar, aqui a literatura tem um teor testemunhal, que nos últimos anos é um conceito que modifica a maneira como os teóricos veem a relação entre literatura e a realidade. Deve-se apreender que na literatura, em seu sentindo de ficção, isto é, com o teor testemunhal, o testemunho jurídico é totalmente eliminado (SELIGMANN-SILVA, 2003).

Assim, adentrando a categoria teor testemunhal parte significativa e imprescindível para demarcar a literatura de testemunho do testemunho jurídico, compreende-se que,

Nos estudos de testemunho deve-se buscar caracterizar o teor testemunhal que marca toda a obra literária (mas, repito, que aprendemos a detectar a partir da concentração deste teor na literatura e escritura do século XX). Este teor indica diversas modalidades de relação metonímica entre o "real" e a escritura. Em segundo lugar, esse "real" não deve ser confundido com a "realidade" tal como ela era pensada e pressuposta pelo romance realista e naturalista: o real que nos interessa aqui deve ser compreendido na chave freudiana do trauma, de um evento que justamente resiste à representação. (Seligmman-Silva, 2008b, p. 1)

Ao que está supracitado, entende-se que o teor testemunhal é uma categoria da literatura de testemunho que se usa da simbologia (visão subjetiva da realidade) e de uma linguagem - abjeta - característica do testemunho para narrar experiências traumáticas, que acabam por simular o real. Essa nova concepção de trauma na literatura, destaca a situação de choque que não pode ser percebida em sua totalidade, aqui o teor testemunhal entra como uma narração ao mesmo tempo que fictícia, mas também de uma exposição não completa desses fatos. "Daí Freud destacar a repetição constante, alucinatória, por parte do "traumatizado" da cena violenta: a história do trauma é a história de um choque violento, mas também de um desencontro com o real (em grego, vale lembrar, "trauma" significa ferida)" (Seligmann-Silva, 2003, p. 49).

Seligmann-Silva (2003) com o uso da metáfora, em uma entrevista para o programa Diálogo sem Fronteira ${ }^{2}$, informa que o trauma na literatura é como uma ferida psicológica que precisa de cuidados, assim deduz-se que a experiência traumática traz à tona as dores do traumatizado, em que a ficção ao jogar com o "real" e seus desencontros - ficção-, expõe-se as feridas de um povo silenciado, marginalizado e oprimido, que passa a "ter seus cuidados" ao darem voz e permitir que os acontecimentos possam ser vistos pelo ponto de vista do violentado. Assim,

A linguagem/escrita nasce de um vazio - a cultura, do sufocamento da natureza e o simbólico, de uma reescritura dolorosa do "real" (que é vivido como um trauma).

Aquele que testemunha se relaciona de um modo excepcional com a linguagem: ele desfaz os lacres da linguagem que tentavam encobrir o "indizível" que a sustenta. (Seligamnn-Silva, 2003, p. 48)

Nesse sentido, o teor testemunhal é parte da literatura de testemunho e sua atuação está no fato da narrativa elucidar experiências traumáticas por meio da ficção, com um enredo e personagens que não aconteceram e não viveram na realidade violenta do século XX. Seligmann-silva (2003) exemplifica o teor testemunhal ao citar a obra Les chansons de Billitis de Pierre Louÿs, em que em um de seus comentários ele expõe: "interessa-nos aqui mostrar nessa história, por um lado, que se pode parecer está copiando/traduzindo algo que na verdade está sendo inventado" (p. 376-377), esse trecho corrobora com a marca latente do teor testemunhal - a ficção-, já que ele apresenta acontecimentos que algumas pessoas passaram realmente no pósguerra, assim, apresenta-se como uma verdade, quando comparada aos fatos que aconteceram. No entanto, não se pode esquecer que se trata da criação de personagens e enredos, de uma ficção.

Então, ao que até o momento fora elucidado acerca da literatura de testemunho e teor testemunhal, resume-se de maneira clara, que a literatura de testemunho é entendida como esse jogo entre o "real" e a ficção, já que o testemunho por si

${ }^{2}$ Link da entrevista: https://www.youtube.com/watch?v=tDpg8E-3qbA 
só é indizível, o teor testemunhal é a ficção - a simbologia e a escrita testemunhal - necessária para expor, denunciar e mostrar acontecimentos do século XX, trata-se de uma categoria basilar para que se delimite a literatura de testemunho do testemunho jurídico.

Ocorre uma revisão da noção de literatura justamente porque do ponto de vista do testemunho ela passa a ser vista como indissociável da vida, a saber, como tendo um compromisso com o real. Aprendemos ao longo do século XX que todo produto da cultura pode ser lido no seu teor testemunhal. Não se trata da velha concepção realista e naturalista que via na cultura um reflexo da realidade, mas antes de um aprendizado - psicanalítico - da leitura de traços do real no universo cultural. Já o discurso dito sério é tragado e abalado na sua arrogância quando posto diante da impossibilidade de se estabelecer uma fronteira segura entre ele, a imaginação e o discurso dito literário. Não existe uma essência do literário que dê conta de contê-lo diante do discurso dito sério. (SELIGMANN-SILVA, 2008a, p. 71)

Assim, a categoria do teor testemunhal se manifesta na literatura por meio do testemunho simbolizado com uso estético da sua escrita - a voz do oprimido -, essa estética literária se procria na literatura de testemunho para expor as atrocidades que marcam essa nova vertente literária, surgida no pós-guerra para esmiuçar as catástrofes do mundo ocorridas e externadas por meio da voz do marginalizado e subalterno.

\section{Da Tortura ao Corpo Torturado: um Olhar Sobre a Teoria}

Segundo Foucault (2014) a tortura trata-se de uma forma de dominação sobre o corpo, que ocorre por meio da produção de sofrimento, apreciado, comparado e hierarquizado. Em 10 de Outubro de 1975 houve uma assembleia em Tóquio, nela a tortura foi definida, pela associação médica e mundial, como: “A imposição deliberada, sistemática e desconsiderada de sofrimento físico ou mental por parte de uma ou mais pessoas, [...] com o fim de forçar uma outra pessoa a dar informações, confessar, ou por outra razão qualquer.” (Ruiz-Mateos apud Arquidiocese de São Paulo, 1985, p. 01).

Neste caso, ainda Subirats (2006) explana que a tortura é um microcosmo, por isso tem alto valor teológico, filosófico e político, os quais apresentam técnicas físicas e químicas de destruição humana. Então, a tortura se reconfigura sob três definições. A primeira está ligada à destruição humana, humilhação e à morte sacrificial, à cultura da violência que existia por trás da modernidade. A segunda diz respeito à expressão suprema da liberdade, encontra-se ligada a princípios de dominação por razões técnico-científicas e morais, que se manifestam de maneira jurídica e política. A terceira corresponde ao conceito de tortura por um viés estético, pois se encontra ligada às violências de transição nos últimos anos, onde seu significado encontra-se constituído pelos poderes totalitários como o fascismo.

Nessa lógica, uma das características mais marcantes das ditaduras do século XX é a ocultação pública dos atos de tortura. Enquanto as punições das instituições de repressão social da Idade Média utilizavam-se da violência como atos de disciplina social, como método pedagógico perverso de controle da ordem pública por meio do terror. As máquinas ditatoriais modernas aproveitam-se da ocultação dos espaços, métodos e agentes repressivos como táticas para o exercício livre da tortura, além de evitarem o escândalo e as críticas públicas. Consequentemente a noção de carrasco é modificada:

A punição pouco a pouco deixou de ser uma cena. E tudo o que pudesse implicar de espetáculo desde então terá um cunho negativo; e como as funções da cerimônia penal deixavam pouco a pouco de ser compreendidas, ficou a suspeita de que tal rito que dava um "fecho" ao crime mantinha com ele afinidades espúrias; igualando, ou mesmo ultrapassando-o em selvageria, acostumando os espectadores a uma ferocidade de que todos queriam vê-los afastados, mostrando-lhes aa frequência dos crimes, fazendo o carrasco se parecer com criminoso, os juízes aos assassinos, invertendo no último momento os papeis, fazendo do supliciado um objetivo de piedade e de admiração. (Foucault, 2014, p. 14) 
É dentro desse novo modus operandi que a criação de máquinas repressivas que vivem longe dos olhos dos críticos, ou mesmo da sensibilidade da população, se instauram, e o corpo torturado passa a ter um enfoque diferente do que tinha em épocas passadas. A punição do corpo, agora, já não se refere apenas à violência na carne, mas também na sujeição da alma individual, da criação de estruturas de submissão psicológica, ideológica, e isto, com métodos de violência física, mas que objetivavam a deterioração da subjetividade do torturado.

Assim, adentrando ao corpo torturado, Batista e Sarmento-Pantoja (2014) esclarecem que,

Tratar do corpo é abordar o orgânico, no entanto há outros aspectos, isto é, a noção de corpo pode ser estudada levando em consideração o fato de esse pertencer a um conjunto de corpos semelhantes, com os quais estabelece relações (afetivas, sociais, etc.). Assim, a existência é atrelada ao modo como ele se apresenta aos demais e às relações estabelecidas entre eles, ou seja, o corpo é pensado a partir de uma ideia de conjunto; de semelhantes que estabelecem relações entre si e reconhecem traços não partilhados, que conferem ao corpo a distinção/unicidade capaz de permitir a ele ser, ao mesmo tempo, semelhante e único. Esse processo de definição do corpo engloba, ainda, uma dimensão imaterial composta por sentimentos e vivencias experimentada de modo único, individualizado. (p. 110)

Paradoxalmente, a máquina repressiva criada na ditadura militar no Brasil se deu de forma a adquirir legitimação da violência contra os subversivos e, portanto, inimigos da ordem pública, daí, os atos praticados contra comunistas passaram a ter caráter de proteção da sociedade por meio do Estado, porém, essa mesma política causava o terror na população civil. Diante disso, novamente, Batista e Sarmento-Pantoja (2014) assinalam que:

Ao tratarmos da tortura estamos diante de um ato de violência, que adquiriu, durante o Regime Militar, status de política de Estado, sendo um dos principais responsáveis pela instalação de uma atmosfera de terror e opressão sentida pela população. Sensação, ora advinha da possibilidade de sofrer essa violência, e ora das marcas, muitas vezes invisíveis, que a tortura imprimia nos corpos; vestígios latentes permanentes na vida das vítimas, mesmo anos após vivenciarem as experiências traumáticas. (p. 109)

Assim, o corpo torturado passa a ter não apenas a função de punição de um delito proporcionado ao crime, mas uma destruição total da capacidade intrínseca de autoafirmação, subjetividade e convicções pessoais. O torturador busca exaurir do torturado, mediante o terror psicológico, as marcas no corpo e as lembranças que delas se depreendem à mente da vítima, a capacidade de reorganizar-se, de voltar à defesa daquilo que crê e daquilo que porta como um ideal, uma causa, um sonho. O corpo torturado é, portanto, o de um indivíduo que carregará para sempre as cicatrizes de uma submissão violenta, que o paralisará ante a presença do torturador e das instituições repressivas em que foi aniquilado.

Com base nessas observações, pode-se atestar que o corpo torturado é reduzido a condições subumanas, e a visão do corpo torturado ao torturador é associada a características animalescas. O corpo torturado está marcado para sempre com o trauma advindo da violação do seu corpo e, consequentemente, de sua mente. É preciso ter consciência de que,

Ferido, torturado, esquartejado, virado do avesso, rompida a superfície lisa e sensível da pele, expostos os órgãos que deveriam estar bem abrigados - ainda assim isso que que nos aproxima do horror e nos remete ao limite do Real continua sendo um corpo. Um corpo roubado a seu próprio controle -corpo que não pertence mais a si mesmo e transformou-se em objeto nas mãos poderosas de um outro, seja o Estado ou o crime; um corpo objeto do gozo maligno de outro corpo. (Kehl, 2004, p. 9-10)

Essa condição a que o corpo é submetido faz com que fique claro as motivações e a essência dos sistemas que a permitem e a promovem, mostram a índole sanguinária e sádica dos torturadores em relação aos torturados. Dessa maneira, o corpo torturado passa a ser joguete nas mãos de torturadores sádicos, que fazem com que o corpo a eles submetido se torne 
vítima das mais perversas técnicas de violência, sendo mutilados, violentados em sua dignidade humana, anulados em sua capacidade de individualização, marcados de forma indelével.

\section{Resistência no Escrito de Haroldo Maranhão}

Haroldo Lima Maranhão foi um prosador paraense, amazônico, brasileiro, nascido em Belém do Pará, no dia 7 de agosto de 1927, falecido no dia 15 de julho de 2004, em Petrópolis, no Rio de Janeiro, aos 76 anos. Segundo Alves (2006), de maneira irônica assume a posição de escritor e mediador que despedaça o que até então está estabelecido, o faz por meio do discurso literário, o que não deixa de problematizar os fatos históricos, retomando acontecimentos que já ocorreram, sendo sua escrita uma descrição memorialista e irônica que detalha aspectos históricos e sociais do Brasil.

Nesse viés, o conto O Leite em Pó da Bondade Humana, de Haroldo Maranhão surge em 1975 na coletânea de contos Chapéu de três bicos, livro publicado em tiragem limitada, com apenas 200 cópias. Após o recuo de ações repressivas durante a ditadura militar, no início de 1980, o livro passa a compor a coletânea Peles Frias, publicada posteriormente no ano de 1983, passando a circular de maneira mais abrangente. Em diálogo com a realidade militar brasileira, a ficção, objeto de análise deste estudo, associa seus fatos narrados à organização política, cultural e às perseguições aos divergentes dessa ideologia dominante. Haroldo Maranhão constrói literariamente um drama que denuncia as atrocidades militares, ocupando um lugar de fala (a de torturados) que faz justiça aos silenciados pelo sistema opressor.

Trata-se de uma literatura de testemunho, exclusivamente de teor testemunhal, em que todos os fatos narrados são ficção, nada do que está escrito ocorreu em determinado momento da história da ditadura militar no Brasil. No entanto, são fatos que expõem acontecimentos verídicos desse período. Seligmann-Silva (2003) elucida que "o real que nos interessa aqui deve ser compreendido na chave freudiana do trauma, de um evento que justamente resiste a representação” (p. 373). Nessa lógica, vê-se nesses tipos de narrativas, que:

Tendemos a dar voz ao mártir, vale dizer, a responder à sua necessidade de testemunhar, de tentar dar forma ao inferno que ele conheceu - mesmo que o fantasma da mentira ronde as suas palavras. Um texto totalmente ficcional de testemunho, mas que é apresentado como autêntico, mobiliza os autores como se não se trata-se de um texto apócrifo. (Seligmann-Silva, 2003, p. 375-376)

Por esse elo entre ficção e a história possibilitado no conto pela literatura de testemunho:

Entre as décadas de sessenta e oitenta os países da América Latina passaram por ditaduras militares, responsáveis pela violação da justiça e dos direitos humanos através de crimes e abusos de todos os tipos. Uma das marcas desses regimes foi a tortura e o assassinato de milhares de pessoas que se opuseram aos governos autoritários, acompanhados de ocultação de cadáveres, sequestro de crianças, inquéritos com provas forjadas, imposição do medo e censura generalizada. Trabalhos importantes têm sido escritos sobre o papel desempenhado pelas políticas da memória no período de democratização desses países. No Brasil, a ditadura se estendeu de 1964 até 1985 . Já nesse período encontramos grupos e instituições que foram criados com o intuito de denunciar os atos de exceção praticados pelos militares e que deixaram documentos, arquivos e livros que permitem a transmissão da memória para gerações futuras. (Santos, 2020, 291)

Segundo Arns (1987), a datar de 1964, fixa-se no Brasil um novo modelo governamental, conhecido como regime militar, foi um período político nacional marcado na história devido às várias práticas de violência e silenciamento, assim, por meio de atos institucionais, os militares praticavam a censura, a perseguição política, a supressão de direitos constitucionais, a falta de democracia e a repressão a quem era contra o regime ditatorial. Esse período durou 21 anos, até a eleição de Tancredo Neves, em 1985.

Por esse viés, o personagem protagonista, trata-se de um preso político que se opunha ao governo militar no Brasil.

O protagonista do conto de Haroldo Maranhão, que não é nomeado, é preso e torturado, precisamente, para a entrega do paradeiro de Baiano, suposto chefe dos subversivos. 
Cheguei a admitir que me haviam largado, convencidos enfim de que eu nada sabia, quem era o Baiano, onde morava, [...] em que local estava [...] na tarde do dia 3, se o encontro fora no cinema Roxy, ou no apartamento do Grajaú [...]”. [...] que baianos conheço muitos, mas não o dito Baiano? (Maranhão, 1983, p. 11-12)

O protagonista vira um joguete nas mãos dos algozes a violência passa a ser sistematicamente calculada para retirar da vítima a confissão, a deleção de algum suposto companheiro, ou mesmo incutir-lhe o sentimento de culpa necessário para a rendição absoluta ao torturado. O suplício se segue agora partindo para o interrogatório, mesclado do xingamento, pois é por meio do discurso de redução e menosprezo à vítima que se dá início ao processo de tortura psicológica: “- Ã, num sabe não, seu putinho de merda? Olhe só, comandante, ele tá dizendo que não sabe não.” (Maranhão, 1983, p. 12).

Assim, o personagem negava em meio as torturas não conhecer Baiano, no entanto, buscavam saber quem era, e onde ele estava:

[...] Automaticamente repetia as frases estereotipadas no cérebro.

"Não sei quem é. Não sei. Não sei quem é o Baiano. Não sei. Não sei."

Pude falar mais alto:

“Caralho! Não compreenderam que eu não sei?” (Maranhão, 1983, p. 16)

Ao se considerar o contexto literário e a temática da tortura, o conto O Leite em Pó da Bondade Humana de Haroldo Maranhão revela um cenário repleto de meios de violência que ocorreram no período ditatorial. O texto já inicia descrevendo cenas de tortura, a forma como são tratados os presos políticos, com o uso de uma linguagem sinestésica, de baixo calão, o autor, de imediato, relata a indignação, o sufocamento e a angustia que sentia o personagem durante as sessões de violência.

O FILHO da puta agarrou-me pela camisa com a mão esquerda, levantou-me do soalho como se levantasse um menino e derrubou-me: um soco no centro da cara. A dor não sei como suportei, que o golpe trazia o peso e a potência da raiva. O sangue vazava do nariz e invadia-me a boca. Eu resfolegava feito um bicho morrendo, e quando aspirava, entravam golfadas mornas, que em seguida refluíam ensopando e tingindo a camisa. Rolei e de bruços, com as mãos protegi as orelhas e a fonte, retesei as pernas para resguardar o sexo, iludido de que a providência evitasse tudo ou mais. (Maranhão, 1983, p. 11)

Ao iniciar o conto com essa narração dos primeiros atos de agressão física, Haroldo Maranhão expõe aquilo que se pode chamar de violência voluntária, quando, apesar da imobilidade da vítima, o torturador usa da força, da pancada, como amostra intimidatória e determinação de papéis, isto é, o algoz e vítima, superior sobre o inferior, torturador sobre torturado.

"Eu resfolegava feito um bicho morrendo" (Maranhão, 1983, p. 11). Essa sentença corrobora exatamente a atitude de submissão e subumanidade que a máquina de tortura requer de suas vítimas, a consciência de diminuição e, quiçá, a anulação completa de sua dignidade humana. O protagonista desse conto, em linguagem explícita, assinala o estado de violência psicológica e corporal a que o processo de tortura submetia suas vítimas, debalde de toda a esperança ilusória de “uma providência que evitasse tudo ou mais" (Maranhão, 1983, p. 11). O indivíduo torturado busca proteger-se escondendo os pontos mais dolorosos, mas são justamente as regiões de extrema sensibilidade que o algoz deseja atingir.

É notório essa descrição bem apurada dos atos de violência, usa-se até mesmo de termos de animalização, sendo uma forma de o autor evidenciar de maneira mais real o que há nas sensações de tortura.

Quando me relaxava, certo de que no chão ficaria em algum repouso, recebo patada no rim esquerdo, outra, mais outra, de todos os lados, punhais de couro quase rompendo-me a carne. Meus dentes sem explicação não se partiam, pressionados uns sobre os outros, cimentados, ou soldados, para não deixar fugir os gritos, que socava na garganta; não urrava, a cada ponta pé e gemia, gemido só por mim percebido, [...] voltaram-me o peito para cima, enquanto vibravam pancada no escroto, que me desacordou. (Maranhão, 1983, p. 13, grifo meu) 
Diante dessas torturas, o personagem recobra as forças para manter-se consciente, lúcido, e percebendo isso, os encarregados de seguir o processo interrogatório iniciam uma nova série de pancadas e ataques ao corpo já chagado do prisioneiro, pois é necessário enfraquecer todas as forças restantes da vítima.

Assim, tem-se um processo de animalização da vítima, que mesmo reduzido a uma condição subumana, o corpo torturado permanece com aparência de ser humano, ainda que aviltado, mutilado, restando assim ao torturador e à máquina ditatorial impingir a humanidade da vítima apenas algo de caricatura da verdadeira humanidade, a qual eles próprios, os torturadores, representam e usam como modelo de civismo, ordem e dignidade.

Outro ponto a essas torturas é o alvo do ataque, motivado por questões subjetivas, de autoafirmação da sexualidade, na tentativa de desvirilizar o torturado. É a genitália o alvo, bem como a virilidade do corpo agredido que visa tal mutilação. “Te serve aí, Mãozinha." (Maranhão, 1983, p. 15). Mãozinha era conhecido pelo fato de portar patas de fera embutidas nos punhos. Assim relata o personagem:

A frase veio-me nítida, eu a escutara certamente, e sepultada ficou quanto tempo?'

"Te serve aí Mãozinha."

Eram muitos, revezavam-se, sempre visavam á genitália, como se meu sexo lhes fosse insuportável, como se precisassem estragar-me aí justamente, emascular-me, para não enrabar nunca mais as putas que os cagaram. (Maranhão, 1983, p. 15)

Diante dessas torturas o personagem interroga-se: “Teriam me capado? Verdade é que mexer-me era impossível, a articulação do braço partida certamente, a mão esmagada, o que mais me teriam inutilizado? Os cúleos.” (Maranhão, 1983, p. 18). A palavra cúleo, obsoleta e em desuso, introduz no texto uma reflexão que o personagem faz quando vai buscar nas profundezas de sua memória as recordações das mais antigas formas de tortura e, assim, atormentados por esses conhecimentos longínquos, agora, já não mais descrições de fatos passados e sofrimentos de terceiros, mas ao contrário, ameaças eminentes, donde ele era a vítima, o castigado. A tortura do conhecimento prévio da dor.

É nesse contexto de violência assinalado que se discute a temática da tortura. No livro Literatura e Resistência, Bosi (2000, p. 120) escreve que "a resistência se dá como tema", considerando o significado da palavra resistir, compreende-se que o autor atribui essa definição ao sentindo de se manter firme, de não ceder ao choque causado pelo outro, assim, o tema nos textos de resistência traz vida, estímulo para se ir contra o choque, consequentemente traz a liberdade necessária para expor uma realidade silenciada que de maneira gradativa se expõe por meio do símbolo.

É nesse contexto que o conto de Haroldo Maranhão, usando em seu escrito o teor testemunhal, não aborda a velha concepção realista e naturalista que via na cultura um reflexo da realidade, mas antes de um aprendizado - psicanalítico - da leitura de traços do real no universo cultural. Já o discurso dito sério é tragado e abalado na sua arrogância quando posto diante da impossibilidade de se estabelecer uma fronteira segura entre ele, a imaginação e o discurso dito literário. (Seligmann-Silva, 2008a). Aqui a linguagem simbólica do teor testemunhal mostra-se com a exposição dos acontecimentos nesse período de violência, em que se reverbera por meio da teoria do choque freudiano da "ferida que precisa de cuidados", isto é, da fala por um mediador aos silenciados, aos oprimidos que passam a ser lembrados.

Segundo Calveiro (2006), a primeira função da tortura está na intenção de iniciar no prisioneiro uma ilegalidade estatal, marcando sobre o seu corpo as novas regras, impondo limites e respeito ao mundo e sobre o direito de protegê-lo. A segunda função está ligada à intenção de obter informações úteis que o preso sequestrado pode ter. Este foi o objetivo que a tortura atuou de maneira mais eficiente. Outro ponto de atuação da tortura é quanto a sua atuação como uma mensagem de aviso a todos, já que das vítimas cria-se efeitos sobre a sociedade.

Portanto, dialogando entre a narrativa e a teoria percebe-se que a tortura, aqui relatada, parte de uma finalidade em forçar o outro a deliberar de acordo com as vontades do torturador. Segundo o projeto "Brasil: Nunca Mais" da Arquidiocese 
de São Paulo (1985), a tortura visa o avesso a liberdade, com um discurso busca por intermédio da intimidação e da violência alcançar seus objetivos, sendo ela tudo o que venha a causar dor, pânico, desgaste físico e mental, provocando disfunções no corpo e nas faculdades mentais, bem como prejuízo a moral.

Assim, diante das discussões apresentadas percebe-se que a denúncia da tortura no conto, torna conhecido os meios de violência que eram utilizadas nos cárceres durante a ditadura militar; observados a partir do tema trabalhado (tortura), encontrando-se uma descrição profunda e sentida das torturas ao corpo e ao psicológico.

Mesmo Maranhão não as vivenciando em cárcere, lembrando que “[...] não só aquele que viveu um martírio pode testemunhar, a literatura sempre tem um teor testemunhal" (Seligmann-Silva, 2003, p. 48), ele consegue colocar em seus escritos, de maneira veraz, as dores sentidas após a tortura, descrevendo uma realidade que ainda choca o Brasil.

Faltavam-me respostas para as perguntas que me assaltavam. Não sabia estimar a gravidade das lesões. Ardia a garganta e agredia-me sede intensa, fome não, mas sede, e na boca o travo de sangue, mijo e merda. O não cuspir angustiava-me, nem ao menos conseguia umedecer os beiços chagados. A dor cobria o corpo até as unhas dos pés [...]. Para mim, um mínimo de força recobrada significava onipotência: comandante dos meus sentidos, reconhecia as coisas ao redor, situava-me, embora fisicamente reduzido à semi-imobilidade. (Maranhão, 1983, p. 14)

Partindo do corpo inerte e pisado pela dor, a personagem busca um refúgio, uma fuga da realidade que o rodeia, mantém-se imóvel, “os olhos apertados, as mãos rigidamente aplicadas aos ouvidos, como se vedá-los me encapsulasse em esfera de aço, que força alguma romperia" (Maranhão, 1983, p. 11), assim, amainadas a pancadaria, "nada sucedia além do silencio e da minha tensão" (Maranhão, 1983, p. 11), relata o torturado.

Neste contexto, a definição de corpo ganha um novo aspecto; um novo nome: o de vítima. Pois o corpo sob tortura não é um corpo qualquer, mas aquele que foi objetificado por meio de um processo violento; impetrado por um indivíduo, seu igual enquanto forma (corpo), porém superior em relação ao poder. O corpo-vítima torna-se, nas mãos de seu agressor, destituído de seus traços humanos. (Batista et al., p. 03).

Em Maranhão são destacadas a situação do corpo e do psicológico após as torturas, a vítima torna-se um objeto nas mãos do algoz.

Quando me relaxava, certo de que no chão ficaria em algum repouso, recebo patada no rim esquerdo, outra, mais outra, de todos os lados, punhais de couro quase rompendo-me a carne. Meus dentes sem explicação não se partiam, pressionados uns sobre os outros, cimentados, ou soldados, para não deixar fugir os gritos, que socava na garganta; não urrava, a cada ponta pé e gemia, gemido só por mim percebido, quando um coice me acertou no calcanhar nu, irradiando descarga elétrica até a nuca: a perna perdeu o comando, foi afastada, voltaram-me o peito para cima, enquanto vibravam pancada no escroto, que me desacordou. (Maranhão, 1983, p. 13).

O conhecimento do torturador sobre anatomia humana, ou seja, a região certeira do golpe, as suas implicações fisiológicas, tensionais, demonstram que a aplicação dos tormentos físicos e psicológicos eram mais que pura descarga do ódio por meio da força: eram atos calculados e colhidos da experimentada tradição de práticas de tortura dentro das escolas de formação militar.

Somada às dores corporais e psíquicas, a mão da tortura não se contenta em causar apenas feridas e hematomas, é preciso aviltar a condição humana da vítima, e para isso recorrem à redução do corpo torturado ao abjeto, não é suficiente ao carrasco quebrar os ossos, mutilar as carnes e membros externos do seu submetido, faz com que se revire em fezes e urinas.

Comecei a definir, na boca, induvidoso gosto: de urina e merda. Isso acordou-me plenamente, como se com força me puxassem as orelhas ou me enfiassem aceso um charuto no cu. Não podia mover-me, creio que apresentava fraturas ósseas, só deviam ser fraturas, nem com as mãos alcançava os lábios e o nariz para remover os dejetos, 
cuspir não conseguia, e angustiado ansiava por livrar-me da imundície, usando se pudesse a camisa como esfregão. (Maranhão, 1983, p. 13)

As situações do corpo eram muitas após as torturas, incluindo o psicológico, que no caso desse conto leva seu personagem a delírios. "O grito retirou-me da letargia [...], após hiatos de lucidez. Sentia febre, elevada porque delirava, à minha frente transitavam como num palco fatos miúdos e remotos, os quais nunca me ocorreram, nunca". (Maranhão, 1983, p. 20).

Nessa lógica, após evidenciar todo esse processo de resistência por intermédio do teor testemunhal, a narrativa com o uso temático da tortura e do corpo torturado, "expõe uma contrapartida dentro das investigações literárias, nos seus aspectos gerais ligados à história social, levando a um novo meio de observação literária do texto em seus aspectos históricos e sociais". (Machado \& Pageaux, 2011, p. 115).

A literatura de testemunho evidencia uma peculiar capacidade dos seus escritos em entrecruzar a literatura e o "mundo fenomênico", essa relação se delimita em seus escritos pela exposição do real pela antimimética e antiirônica (Seligmann-Silva, 2003). No conto de Maranhão esses pressupostos encontram-se bem demarcados. Primeiro, que a linguagem utilizada é uma marca muito bem representativa desse processo, já que os termos utilizados, a linguagem usada pelo narradorpersonagem deixa claro os sentimentos diante da violência sofrida, as descrições latentes com a presença do abjeto, não deixa dúvidas acerca da exposição inconfundível diante da dor e da indignação aos acontecimentos.

Assim Haroldo Maranhão se usa da realidade violenta vivenciada pelos presos políticos durante os anos de chumbo no Brasil, com as torturas braçais e criação de máquinas ditatoriais para descrever justamente como ocorriam às brutalidades em salas de tortura, como os estupros, pau-de-arara, choques elétricos, dentre muitos outros meios. Seu escrito se apresenta não apenas como representação desse passado, mas como denuncia, exposição, um passado que segundo as teorias de Seligmann-Silva (2003) se faz ativo no presente.

Sendo assim, dentro dessa análise, a temática da tortura e do corpo torturado entra como um processo de conhecimento e reflexão acerca das brutalidades cometidas na época da ditadura militar, tal processo se dá por meio da linguagem simbólica dos tipos de tortura apresentados no texto, bem como pelas questões sociais e culturais que neles encontra-se representadas.

\section{Considerações Finais}

Finalizando essa proposta de reflexão teórica, ao analisar o conto O Leite em Pó da Bondade Humana, de Haroldo Maranhão, enfatiza-se que a presente obra se trata de uma narrativa de teor testemunhal, a partir da literatura de testemunho, em que com uma linguagem simbólica, mostra os acontecimentos históricos de violência na ditadura militar ocorrida no Brasil a datar de 1964.

Em vista disso, Haroldo Maranhão em seu conto denuncia por meio de variados meios de tortura, a realidade vivida por presos políticos nos anos de chumbo, considerando as teorias que demarcam a literatura de teor testemunhal, o autor assume o lugar de mediador para evidenciar uma realidade violenta que não vivenciou, mas que lhe foi próxima a sua profissão jornalística e seus vínculos afetivos enquanto escritor.

A temática da tortura torna-se o ponto central de análise do conto, que entra como um difusor já que descreve os meios de violência pertencentes a um momento histórico da sociedade. A partir da análise percebe-se um nível de elaboração da realidade, muito bem discutido por Candido (2000) em que o autor, da sua literatura, instaura-se como um sistema simbólico chamado de tripé sistêmico (escritor, público e linguagem) que aqui nesta análise funciona como um processo de 
denúncia, de ser ouvido diante de fatos históricos que perante os textos ganham força, pois se relata algo silenciado, mas que fez parte da história.

Nessa lógica, o conto apresenta relatos históricos e memorialistas da atuação política militar no Brasil durante a ditadura militar. Assim, a tortura passa a ser um ponto chave nessa obra, como instrumento temático, evidencia um vasto uso dessas atrocidades, que vão de violências braçais a máquinas criadas para o uso opressivo desse governo, testemunhando um lado da atuação militar velado pela política de Estado.

O corpo torturado é uma consequência aos atos de tortura, é as marcas físicas e psicológicas carregadas pela vítima. Ele passa a ser visto como um objeto de posse nas mãos do agressor, refém da crueldade do seu algoz, encontra-se abaixo da condição humana.

Sendo assim, ao abordar a temática da tortura e do corpo torturado no conto de Haroldo Maranhão, compreende-se a importância de uma análise híbrida da história e da literatura dos anos de chumbo no Brasil, para que haja um esclarecimento mais firme acerca dos acontecimentos violentos que ocorreram nesse período, sendo um estudo de grande aposta nas análises de acontecimentos sociais, políticos e históricos que se desencadearam no século passado, mas que ainda deixam marcas no presente.

A hermenêutica histórica ao propiciar o elo interdisciplinar entre o social, a história e a ficção fora de extrema importância para que se pudesse desenvolver este trabalho, já que possibilitou que se adentrasse o período da ditadura militar no Brasil bem como a atuação política contra os presos políticos desse período para compreender as violências ditatoriais na ficção.

Portanto, ao que está supracitado percebe-se a genialidade de Haroldo Maranhão. A partir do seu escrito histórico ficcional, de teor testemunhal, continua a cativar leitores e pesquisadores através do tempo e do espaço, o qual propicia elucidações críticas necessárias e significativas no meio acadêmico, em que marca positivamente o mundo literário contemporâneo.

\section{Referências}

Alves, S. A. G. (2006). Fios da Memória: jogo textual e ficcional de Haroldo Maranhão. Belo Horizonte, 2006.233 f. Tese (doutorado) - Programa de PósGraduação em Letras, Universidade Federal do Paraná.

Arns, Dom Paulo Evaristo (1987). Brasil: nunca mais. Vozes.

Arquidiocese De São Paulo (1985). Brasil: nunca mais: As torturas. Arquidiocese de São Paulo.

Batista, S. M. \& Sarmento - Pantoja, T. (2014). Torturador e torturado: notas sobre ficcionalização do trauma nos contos pós -64. Olho d'água., 6(2), 108119.

Bosi, A. (2000). Literatura e Resistência. Companhia de Letras.

Calveiro, P. (2006). La decisión política de torturar. In: Subirats, Eduardo. Contra la tortura. México: Fineo.

Candido, A. (2000). Formação da literatura brasileira: momentos decisivos. (6a ed.), Editora Itatiaia Ltda.

Carvalhal, T. F. (2006). Literatura Comparada. (4a ed.), Editora Ática.

Foucault, M. (2014). Vigiar e Punir: Nascimento da prisão. Tradução de Raquel Ramalhete. Vozes.

Goldman, P. (1994) Searching For History in Organizational Theory: Comment on Kieser. Organization Science. 5(4)

Kehl, M. R (2004). Três perguntas sobre o corpo torturado. In: Keil, I. \& Tiburi, M. (Org.). O corpo torturado. Escritos, 09-19.

Machado, Á. M. \& Pageaux, D. (2011). Da literatura comparada à teoria da literatura. (2a ed.), Presença.

Maranhão, H. (1983). O Leite em Pó da Bondade Humana. IN: Maranhão, Haroldo. Peles Frias. Alves Editora S. A.

Marco, V. (2004). A literatura de testemunho e a violência de estado. Lua nova $\mathrm{n}^{\circ} 62$. 
Research, Society and Development, v. 11, n. 2, e25511225755, 2022

(CC BY 4.0) | ISSN 2525-3409 | DOI: http://dx.doi.org/10.33448/rsd-v11i2.25755

Ramos, W. F. (2019). A literatura no horizonte da perversão e da abjeção. Santos, Rosana Cristina; Benatti, André Rezende. O lugar do abjeto: Do perverso e do animal na historiografia e no cânone literário. Pelotas: Editora UFPEL.

Santos, M. S. S. (2021). Memória e ditadura militar: Lembrando as violações de direitos humanos. Tempo Social, revista de sociologia da USP, 33(2), 289309.

Sarmento-Pantoja, A. (2019). O testemunho em três vozes: Testis, Superstes e Arbiter. Literatura e cinema de resistência, Santa Maria. N 32: Manifestações estéticas dissidentes, 5-18. http://dx.doi.org/10.5902/1679849x35461

Sarmento-Pantoja, T. (2014). Cinema e Literatura: Resistência Política e Representações do Herói Guerrilheiro em "Pessach, A Travessia" e "Cabra-Cega". Nonada: Letras em Revista, 1(22), http://www.Redalyc.org/articulo.oa?jd=512451668009

Seligmann-Silva, M. (2008a). Narrar o Trauma: A questão dos testemunhos de catástrofes históricas. psic. clin. 20(1), 65 - 82.

Seligmann-Silva, M. (2008b). Testemunho da Shoah e literatura. In: Portal Rumo à tolerância. Aula ministrada no curso Panorama Histórico do Holocausto. < http://www.rumoatolerancia.fflch.usp.br/files/active/0/aula_8.pdf>.

Seligmann-Silva, M. (2010). O local do testemunho. Tempo e argumento. 2(1), 3 - 20.

Seligmann-Silva, M. (org.) (2003). História, memória, literatura: o Testemunho na Era das Catástrofes. Campinas: Editora da UNICAMP.

Subirats, E. (2006). El goce totalitario. In: SUBIRATS, Eduardo. Contra la tortura. Fineo. 